NBER WORKING PAPER SERIES

\title{
PUZZLES OVER INTERNATIONAL TAXATION OF CROSS BORDER FLOWS OF CAPITAL INCOME
}

\author{
John Whalley
}

Working Paper 8662

http://www.nber.org/papers/w8662

\author{
NATIONAL BUREAU OF ECONOMIC RESEARCH \\ 1050 Massachusetts Avenue \\ Cambridge, MA 02138 \\ December 2001
}

A first draft of this paper was presented at a conference on World Tax Competition and held at IFS, London, May 2001. I am grateful to conference participants, and especially Ron Davies and Jim Hines for helpful comments. Hui Huang has provided outstanding research assistance, and Mike Devereux provided helpful comments and literature suggestions on an earlier draft. I acknowledge ESRC for grant support for this work. The views expressed herein are those of the author and not necessarily those of the National Bureau of Economic Research.

(C) 2001 by John Whalley. All rights reserved. Short sections of text, not to exceed two paragraphs, may be quoted without explicit permission provided that full credit, including (C) notice, is given to the source. 
Puzzles Over International Taxation Of Cross Border Flows Of Capital Income John Whalley

NBER Working Paper No. 8662

December 2001

JEL No. F2, H2, H3

\begin{abstract}
I discuss the tax treatment of transborder capital income, focussing on prevailing arrangements rather than de novo design of optimal tax arrangements. These comprise unilateral reliefs from double taxation under credit or exemption systems, and treaty reliefs (largely following the OECD model treaty) which jointly lower withholding tax rates on interest, dividends, and royalties in both host and source countries. I suggest that these arrangements involve both seemingly non-strategic unilateral actions and cooperative arrangements which are difficult to reconcile both with tax competition literature and with national interest. I pose four puzzles in this regard. The first is that from a national welfare point of view, the unilateral reliefs in use seem inferior to no relief since with competitive markets investors equate the private return on investments at home and abroad, while tax revenues largely accrue to the foreign government. Private returns are equated, but national returns are not. The second is that tax treaties only have lump sum effects between national governments if the more common credit arrangements of unilateral reliefs apply and if tax rates are similar in host and source countries (approximately the OECD situation). This raises the issue of why governments negotiate them. The third is the sharp contrast to international treaty arrangements for goods flows under the WTO; and the fourth is the absence of side payments in tax treaties. The picture emerging is that making sense of present arrangements from a national welfare point of view and in terms of efficient instrument design seems difficult. The gap relative to optimal tax considerations also seems large.
\end{abstract}

John Whalley

Centre for the Study of Globalisation and Regionalisation

University of Warwick

Coventry CV4 7AL

United Kingdom

and NBER

J.Whalley@warwick.ac.uk 


\section{INTRODUCTION}

The theme of this collection of papers is worldwide tax competition. ${ }^{2}$ Here I focus on the tax treatment of transborder flows of capital income because, in my view, arrangements actually in use in this area are characterized as much by cooperation, through treaties, as by competition. Tax treaties are negotiated pairwise between countries (typically following the OECD model treaty). Under these, pairs of countries agree to mutually reduce withholding tax rates on bilateral flows of interest, dividends, and royalties to rates below those applying in the absence of treaties. Different tax rates apply to these three categories, and also between different pairs of countries. These treaties clearly represent cooperative behaviour by national governments. Also, unilateral reliefs from double taxation seemingly embody no strategic response to taxes abroad, and have remained invariant to tax redesign in host countries for many years and there is no indication that countries rearrange these reliefs to reflect the actions of other countries. They are offered by source countries and typically involve a foreign tax credit, although in some countries systems of exemption from domestic taxes operate if taxes are paid abroad.

Somewhat surprisingly there seems to be relatively little that has been written by academic economists on this combined system of reliefs and the cross country cooperation in tax arrangements that seem so prevalent. An early paper by Hamada (1966) shows how in the two (non small) country case, source and host countries have incentives to use retaliatory tax policies toward income generated by transborder investments. Hamada characterizes a Nash equilibrium in the 2 country tax game in ways which are closely related to Johnson's earlier (1954) characterization of a 2 country tariff game involving goods flows. He sets out the resulting noncooperative (Nash) tax arrangements, suggesting that incentives to cooperate across countries in this area are large and this should occur through tax treaties. Hamada, however, neither characterizes the form that treaties should take nor discusses unilateral reliefs.

In other older literature, outside of Peggy Musgrave's (1969) discussion of US tax treatment of foreign source income, a later book by Adams and Whalley (1977), and a lengthy discussion and

See the recent survey of theories of tax competition in Wilson (1999). Razin and Slemrod (1990) is the source for key pieces on tax treatment of international capital income. 
evaluation of US tax treatment in the area by Ault and Bradford (1990), there is little which seeks to evaluate arrangements actually in place in this area. What is more common is discussion of optimal tax treatment of capital in the presence of factor mobility; such as in Gordon (1986); or discussion of the content of legal texts of actual agreements, mainly by lawyers, and much appearing in the Bulletin of the Bureau for International Fiscal Documentation (see (1999) for a recent sample issue).

Rather than attempting to characterize optimal tax treatment by country (either jointly or singly), here I discuss arrangements actually in place in this area and pose four puzzles which seem to be raised by these arrangements, yet that the literature has seemingly largely overlooked. The first is that it is hard to find a clear rationale for any system of unilateral reliefs (either credit or exemption) in terms of national interest. This is because in the simple case where domestic and foreign tax rates are the same, if domestic investors equate the net of tax return on investments made domestically and abroad, then under a system of either credit or exemption unilateral reliefs foreigners receive the tax proceeds on foreign investments while the domestic government receives taxes on domestic investments. Private returns across investment vehicles may be equalized, but national returns are not. National interest seems to point to neither foreign tax credits nor deductions for foreign taxes paid.

This first puzzle might strike readers as well known and hence somewhat obvious, but from my reading of the literature it does not seem to be clearly stated in quite this form. Bond and Samuelson (1989) in a paper following on from Hamada and comparing credit and exemption systems come close to such a statement; and Bruce (1992) comes even closer in a paper evaluating why foreign tax credits are offered. But its central statement as a puzzle as to why any recognition is given to foreign taxes in domestic tax codes is not set out in the literature I am familiar with.

The most commonly offered rationale for these reliefs is that in some countries, such as the US, constitutional provisions exclude double taxation, and seemingly in all forms. This may be a convincing legal rationale, but it is hardly economic justification. Some academic writings have actually defended these reliefs by appealing to a general principle of international equity (Richman (1963) and Musgrave (1969)). But no notion of national welfare or interest seems to 
be involved, and the question of why countries use these various types of unilateral reliefs seems to be little discussed and not well understood.

The second puzzle I discuss is that with a system of unilateral reliefs in place, double tax treaties in most cases (i.e. where countries use the more commonly applied credit system of unilateral reliefs and where domestic tax rates are similar across countries) do little to lower the combined tax rates that investors face. Where rates are identical across countries, the effect of bilateral treaties on combined rates (along with unilateral credit reliefs) is zero. This suggests that to the extent that non treaty rates are similar, double tax treaties largely have only lump sum effects in transferring revenues across countries, and in addition largely between tax authorities in the countries. Given that countries are either net recipients of foreign investment from source countries or net investors in these countries abroad, the direction which these transfers take is then given by the net directional flow of investment. This raises the issue of why they are negotiated if the effects are largely lump sum, and what their rationale is if there are alternative instruments for making lump sum transfers.

The third puzzle I raise concerns the sharp asymmetries in institutional arrangements across the forms of policy cooperation towards goods flows impediments through the GATT/WTO and capital flows impediments under double tax treaties. Mundell (1957) long ago argued an equivalence between goods and factor flows in the sense that impediments to goods flows stimulate factor flows, and impediments to factor flows stimulate goods flows. The implication was that what can be achieved from autarchy by allowing for goods flows (factor price equalization, given common international goods prices) can similarly be achieved by allowing for factor flows from autarchy with goods immobility (goods price equalization, given common international factor prices). ${ }^{3}$ This equivalence, one might have thought, would extend to the forms that policy cooperation takes in each of the two areas.

But cooperation in the two areas could hardly be more different; equivalence in cooperative forms does not seem to hold. GATT/WTO arrangements involve multilateral rules and

Subsequent literature, such as Markusen (1983) has focussed on whether goods and factor flows are complements or substitutes. 
negotiations under which key principles such as MFN (non discrimination) are committed to, and dissimilar tariffs are reduced, not harmonized. The issue of special treatment for developing countries also takes centre stage. In contrast, tax treaties are bilateral and no multilateral disciplines apply; tax rates are typically negotiated to be similar in both directions; and as developing countries are net recipients of FDI and their tax rates are high, developed-developing country treaties are fewer. The puzzle here is why are there these glaring differences in institutional form if goods and factor flows are analytically equivalent?

The fourth puzzle I raise concerns the form that tax treaties take, and, specifically, the absence of side payments. To be fair, the absence of side payments in international treaties is a puzzle in many areas, including in trade and environmental treaties. But if tax treaties are difficult to negotiate because one partner to a potential bilateral agreement is a net payer of capital income to the other, side payments would seem the obvious mechanism to support a cooperative agreement. Putting on one side the lump sum argument above, forgone gains from cooperation due to the absence of side payments result from the non-existence of treaties between many developing and developed countries. One can also ask why are tax treaties not linked formally to other international arrangements (such as trade treaties to intellectual property arrangements) to provide for logrolling (or implicit side payments) via concessions on other issues. Why are they stand alone largely symmetric tax rate agreements, which often one party to the agreement is reluctant to negotiate in the first place, or renegotiate subsequently.

In the next section I set out in more detail what current arrangements in this area are, and highlight the limited literature discussion from economists of what explains the presence of these arrangements. ${ }^{4}$ The sections that follow then set out in more detail the four puzzles I raise. I then discusses some possible resolutions for each of them. A final section presents concluding remarks as to where international cooperation in this area may be headed in light of these observations. The paper poses these puzzles more so than resolves them, with some possible reasons tentatively advanced for the seemingly paradoxical structure of these arrangements. Devising more convincing explanations is left as a task for future research.

Although Slemrod's (1988) paper touches indirectly on some of the issues raised here. 


\section{CURRENT INTERNATIONAL TAX TREATMENT OF CAPITAL INCOME}

Current international tax treatment of capital income combines taxation under personal and corporate taxes as set out in the national tax codes of source countries, along with unilateral reliefs from double taxation in source countries ${ }^{5}$ and treaty reliefs bilaterally negotiated between source and host countries which lower withholding tax rates on transborder capital income originating in both countries. The world to which this regime applies is one in which there are significant two way investment flows between most industrialized countries, and the net flows of capital income compared to the gross flows are often relatively small.

\section{Unilateral Reliefs}

Most countries around the world (and states within countries) build policy on the principle that income earned from investment should not be taxed in two states, and hence some form of relief from what would otherwise be double taxation should be given. Such reliefs are typically implemented in one of two forms; granting a credit against domestic taxes owing for (all or part of) foreign taxes paid (a foreign tax credit), or exempting foreign source income from domestic taxes if taxes have been paid abroad. ${ }^{6}$ Credit systems are far more pervasive than exemption systems.

Thus, putting on one side the differences in tax rates on interest, dividends, and royalties that apply in practice across most countries, if $t^{H}$ is the home country tax rate, and $t^{F}$ is the foreign country tax rate; then under a credit system the effective marginal tax rate on investment abroad, $t^{E}$, is given by

$$
t^{E}=\max \left(t^{H}, t^{F}\right) \quad \text { credit system }
$$

Why unilateral reliefs are only operated by source countries and not by host countries is a further puzzle that I do not go into here. Source country reliefs lower taxes in source countries on the basis of taxes previously paid in host countries. Host country reliefs, were they to operate, would lower host country taxes on the basis of taxes to be paid later in source countries. 
while under an exemption system,

$$
t^{E}=t^{F} \quad \text { exemption system }
$$

If $t^{H}=t^{F}$, these two systems are equivalent in impact.

Table 1 documents the form the systems in use in some of the more major OECD countries take. It first sets out whether the sample countries operate credit or exemption systems. Here, among 5 European and 2 North American countries, only one country operates an exemption system. Table 1 also lists the non treaty withholding tax rates that countries use on the three categories of royalties, interest and dividends. Bilaterally negotiated treaties lower these rates, but as can be seen non treaty rates vary across countries and also in some cases across types of income.

Withholding tax rates in the $25 \%$ is a common figure which often thought to loosely characterize this treatment across OECD countries.

See the discussion in Adams and Whalley (1977); Ault and Bradford (1990) provide a comprehensive discussion of and rationale for US arrangements; Hines (1994) discusses credit and deferral arrangements. Hartman (1984, 1985) discusses the impacts of US tax policies on foreign investment. 
$\underline{\text { Table } 1}$

\section{Systems of Relief and Non Treaty Withholding Tax Rates on Payments by Subsidiaries to Foreign Parent Companies ${ }^{1}$}

\begin{tabular}{|l|c|c|c|c|}
\hline Country & $\begin{array}{c}\text { Unilateral } \\
\text { Relief From } \\
\text { Foreign Double } \\
\text { Taxation }\end{array}$ & Royalties & Interest & Dividend \\
\hline Belgium & Credit & $15 \%$ & $15 \%$ & $25 \%^{3}$ \\
\hline Canada & Credit & $25 \%$ & $25 \%$ & $25 \%$ \\
\hline France & Exemption & $331 / 3 \%$ & $15 \%$ & $25 \%$ \\
\hline Germany & Credit & $26.38 \%$ & $26.38 \%$ & $26.38 \%$ \\
\hline Italy & Credit & $22.5 \%$ & $12.5 \%{ }^{2}$ & $15 \%$ \\
\hline UK & Credit & $22 \%$ & $22 \%$ & $22 \%$ \\
\hline USA & Credit & $30 \%$ & $30 \%$ & $30 \%$ \\
\hline
\end{tabular}

${ }^{1}$ Source: Guides to European Taxation Vol. 1: The Taxation of Patent Royalties, Dividends and Interest in Europe published by the International Bureau for Fiscal Documentation, Amsterdam. ${ }^{2}$ For dividends from certain shares issued in 1982 and 1983 the rate in $20 \%$.

${ }^{3}$ In various special cases other rates can apply.

\section{Treaty Reliefs}

Treaty reliefs from double taxation are bilaterally negotiated arrangements between pairs of countries. These co-exist with the unilateral reliefs offered individually by countries and discussed above. Under these treaties three categories of foreign source income are identified (interest, dividends, and royalties) and different mutually lowered tax rates both can be and are negotiated for each of these. Typically treaties are renegotiated from time to time, but these renegotiations are relatively infrequent (in some cases 20-30 years) and renegotiations of one treaty do not overlap with those of others. They generally involve an agreement by the two countries involved to jointly lower the withholding tax rates which they each apply to specific forms of capital income leaving the country (typically, interest, royalties, and dividends). A variety of other provisions also enter such treaties, including agreements by national revenue authorities to exchange information. ${ }^{7}$ The majority of treaties follow, to varying degrees of 
closeness, a model treaty established some years ago under OECD auspices, now known as the OECD model treaty. ${ }^{8}$

Table 2 sets out the tax rates which apply under seven bilateral treaty country pairs for the three categories of income set out above. These treaties are quite complex in practice,, with, in some cases, different tax rates applying within a category depending on special conditions. Withholding tax rates on bond interest may, for instance, differ from those on bank interest. The size of foreign ownership can also influence tax rates, although Table 2 shows them only for the wholly owned subsidiary case.

Table 1 indicates that OECD countries have non treaty withholding tax rates with a mean value of around $25 \%$ on capital income paid abroad, and so bilateral treaties lower these rates and often sharply. They also often involve different rates on the various categories of income. In some cases (category flows between particular pairs of countries) $0 \%$ tax rates prevail, and these rates are common in inter EU treaties, as Table 2 shows.

The bilateral nature of these treaties can also have a significant effect on both the composition and volume of global capital flows. ${ }^{9}$ Countries such as Holland (not included in Table 1 and 2), for instance, are generally thought to have negotiated especially low tax rates in their treaties; which makes them a focal point for a network of international flows. Thus taxes may be lower if payment goes from $\mathrm{A}$ to $\mathrm{C}$ via $\mathrm{B}$, rather than directly from $\mathrm{A}$ to $\mathrm{C}$. Countries with low treaty rates are often also thought to be better connected to tax haven jurisdictions (such as the

See the paper by Mintz and Tulkens (1991) which sets out the OECD model treaty and evaluates its impacts in effectively harmonizing corporate tax regimes. They argue the treaty increases tax exporting but reduces capital flight.

See the discussion of this point in Adams and Whalley (1977). 
Netherlands Antilles), where effectively zero tax rates may apply on income for which repatriation to its ultimate source country is deferred. 


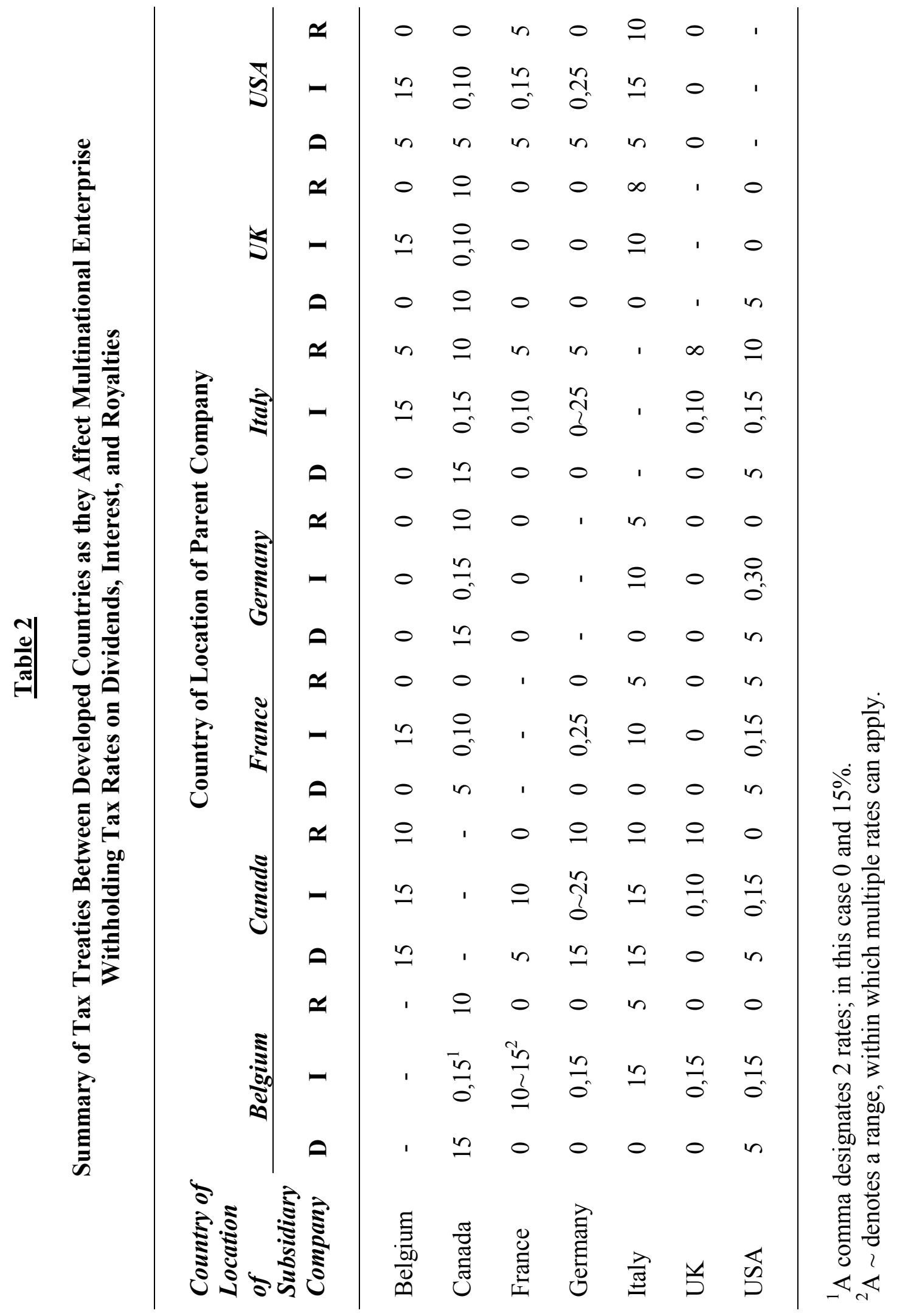




\section{WHY GRANT UNILATERAL RELIEFS?}

The first puzzle raised by this characterization of the prevailing international tax regime for cross border capital income may be stated simply. It is that it is seemingly hard to explain why on the basis of national economic interest countries grant unilateral reliefs.

The reason for posing this puzzle in this way is that will other things being equal (asset risk characteristics, for example) private investors invest across locations so as to equalize their private return on investments. As a result, private returns to investors will be equalized across domestic and foreign opportunities, but the national returns to investments are not. The country to which taxes are paid to is not of any great consequence to investors, but it is clearly of major consequence nationally. Thus, from a national point of view, investments made at home generate tax revenues; while under a system of reliefs as under an exemption system (or alternatively, under a foreign tax credit with similar tax rates at home and abroad) no taxes accrue to the domestic treasury.

This can be shown in the following way. I consider a case where $r^{D}$ and $r^{F}$ denote the gross of tax rates of return on domestic and foreign investments, and $t^{D}$ and $t^{F}$ the domestic and foreign tax rates (assumed for simplicity in this case to be equal). There is a unilateral system of reliefs operating in country $D$, domestic investors placing funds abroad pay taxes at rate $t^{F}$ to the foreign government, but since $t^{D}=t^{F}$ the unilateral credit relief means that no further taxes are paid to the domestic government.

Investors will equate net of tax rates of return on the two alternative investments, and the equilibrium condition in capital markets in this case is that

$$
r^{D}\left(1-t^{D}\right)=r^{F}\left(1-t^{F}\right)
$$

which is what is required for global efficiency of resource allocation. Private returns to investments across the two sources are equalized, but national returns from the viewpoint of country $D$ are not equalized, since these returns are

$$
\text { domestic investments } \quad r^{D}
$$


foreign investments $\quad r^{F}\left(1-t^{F}\right)$

Global efficiency and national welfare are at odds in this case because national and private returns differ; and seemingly, a unilateral credit system does not serve national interest. In the small open economy case, where the size of capital flows has no impact on worldwide rates of return, it is also not desirable from a national point of view to allow either a foreign tax credit or an exemption.

With neither an exemption nor credit system of unilateral reliefs in place, private returns across investment options are

$$
\begin{array}{ll}
\text { domestic investments } & r^{D}\left(1-t^{D}\right) \\
\text { foreign investments } & r^{F}\left(1-t^{F}\right)\left(1-t^{D}\right)
\end{array}
$$

If private returns across investment sources are equalized this implies in this case that

$$
r^{D}=r^{F}\left(1-t^{F}\right)
$$

In this case, the national returns are

$$
\begin{array}{ll}
\text { domestic investments } & r^{D} \\
\text { foreign investments } & r^{F}\left(1-t^{F}\right)
\end{array}
$$

and so relative private and social returns across the two investment sources are the same. Not allowing any credit or exemption reliefs involves a deviation from global efficiency conditions, but it is the national interest that is at issue here and that is best served by such an arrangement.

National interest in this case thus suggests that all investments should generate the same national (i.e. gross of national tax) return per $\$$ invested, irrespective of location of the investment. A foreign tax credit or tax exemption for capital income previously taxed in a foreign country conflicts with this principle by equating private, not national returns. Unilateral reliefs thus seem difficult to justify on national interest grounds.

This may seem a relatively simple point and I thought prior to writing this piece was one which was well understood, but somewhat surprisingly there seem to be few clear or concise statements of it in the literature. Richman (1963) and Musgrave (1969) both frequently referenced as key pieces in the older literature on tax treatment of foreign investment income have discussions of 
how principles of inter-nation equity provide guidance as to appropriate tax treatment of foreign source income in national tax codes. The principle advanced is one under which investors should be treated the same no matter in which country they invest and hence supports the presence of a foreign tax credit, but this discussion is seemingly in conflict with national interest for the reasons I set out above and is hard to understand in application to this area. Ault and Bradford (1990) provide a comprehensive discussion of current (then) US practice, but as far as I can see provide no discussion of national interest in the form stated above. Bond and Samuelson (1989) provide an extension to Hamada's earlier paper which they use to discuss foreign tax credits versus deductions of foreign tax. They note that capital exporting countries generally prefer tax deductions because less tax is surrendered to the foreign country, a point similar to that made here, but do not take their discussion further focussing instead on the trade bias implications of different systems. Bruce (1992) seems to be the lone piece which makes the same argument as here. Bruce poses the dual puzzle of why it is that capital importing countries tax the income of foreign owned capital since the domestic return to capital must rise to yield the same net of tax return, reducing gains from trade, as well as why capital exporting countries give foreign tax credits. He suggests that differential monitoring costs for home and foreign investments might account for these arrangements. In optimal tax literature, neither Gordon $(1986)^{10}$ nor subsequent contributions seems to provide any analysis of actual arrangements currently in place when discussing optimal treatment of foreign investment income, and make no comments on unilateral reliefs.

Why then do national governments grant such treatment if it is seemingly contrary to national interest? One simple answer would seem to be the philosophical belief that double taxation is bad, and that reliefs from all forms of double taxation are merited to avoid compounding of taxes. In the US case, this is reflected in constitutional provisions which expressly require relief from double taxation at national and state level. ${ }^{11}$ In federal states such as the US and Canada such provisions are also aimed at limiting tax competition between jurisdictions and more clearly defining allowable tax fields to be used by each level of government in cooperative taxing

Also see the early optimal tax contribution by Horst (1980).

See also the discussion of formula apportionment in Gordon and Wilson (1986). 
arrangements (tax sharing agreements). The idea is to engage in cooperative rather than noncooperative behaviour on jurisdictional tax rates, so as to yield joint gains.

At international level, if all countries are small no incentives to cooperate in this way apply. In the non small case (as clearly applies to the US and the EU) incentive effects arise and things become more complicated. But even in this case, the unilateral reliefs one finds in place today are not arrangements that have been jointly negotiated between governments. They have arisen at different times and in different ways, even though they may have the appearance of a jointly evolved system. Unilateral reliefs in one country remain unchanged when other countries change their policies. Strategic response in terms of reliefs is not something that seems to characterize the area. There is also no division of a larger tax field in this case between members of a union, as occurs in a federal structure. There is also no meaningful wider constitutional structure between nation states that provides a framework for narrower cooperation on unilateral reliefs. In short, to suggest that unilateral reliefs as presently seen in OECD countries reflect some process of strategic response seems to be wide of the mark.

One could perhaps argue that given the large size of two way investment flows relative to net flows between OECD countries, this system represents implicit collusion between countries around a focal point which has been established over the years. No one country is prepared to depart from their own system of unilateral reliefs for fear that others would do so raising taxes abroad on their own investments. Put slightly differently, foreign tax credits may transfer revenues abroad, but if everyone does it at the same time countries accept a swing and roundabouts argument and the net flows are small compared to the gross. This is, of course, unsatisfactory as an explanation since the single country incentive to depart remains.

This, then, is the first puzzle. Why are unilateral reliefs given if they are seemingly so clearly against the national interest?

\section{WHY GRANT TREATY RELIEFS?}


The second puzzle I raise concerns the negotiation by pairs of governments of bilateral double tax treaties of the form described above; the granting of treaty reliefs. ${ }^{12}$ The puzzle here is that if there are pre-existing unilateral reliefs in each country, putting on one side for the moment the possibility of obtaining deferral advantages by holding funds in tax havens, a negotiated tax treaty which lowers tax rates on bilateral flows of capital income may have little or no effect on the economic behaviour of investors. More specifically, where source countries use a credit system of unilateral reliefs, and tax rates at home and abroad for simplicity, are the same, a bilateral tax treaty will only have lump sum effects. If countries have similar non treaty withholding tax rates on interest, dividends and royalties, the effects of negotiated bilateral tax treaties will predominantly be to generate lump sum transfers between governments, more so than to affect the behaviour of investors. Table 1 suggests that there are differences in tax rates involved by country, and so to see treaties as purely lump sum is perhaps overly strong, but I would argue that the broad thrust of the puzzle remains.

This feature of treaties and their interaction with unilateral reliefs can be seen as follows. If $t^{D}$ and $t^{F}$ are the tax rates in domestic and foreign countries (assumed the same), and $r^{D}$ and $r^{F}$ are the rates of return in the two countries, in the absence of any treaty but in the presence of unilateral reliefs private returns on investments made domestically and abroad, private returns are

$$
\begin{array}{ll}
\text { domestic investments } & r^{D}\left(1-t^{D}\right) \\
\text { foreign investments } & r^{F}\left(1-t^{D}\right)
\end{array}
$$

If a treaty is then negotiated under which withholding tax rates on income paid abroad are reduced by $\lambda\left(<t^{F}\right)$, then in the presence of a credit system of reliefs private returns from these two investment types become

$$
\begin{array}{ll}
\text { domestic investments } & r^{D}\left(1-t^{D}\right) \\
\text { foreign investments }^{13} & r^{F}\left(1-\lambda-t^{D}\right)+\lambda r^{F}
\end{array}
$$

See Janeba (1995) for other recent literature on this set of issues.

Here, the domestic tax rate applies to gross foreign source income, before the foreign tax credit is granted. 
Private returns remain unaffected by the treaty in the case where $t^{D}=t^{F}$, but returns to national governments are affected since $\lambda$ is effectively transferred from the host country to the source country.

Why then do countries that are net recipients of inward foreign investment negotiate what are, in effect, lump sum transfers to other governments? Why make transfers in this way when other instruments are available?

Some explanations are that both investors and governments think that, despite the argument above, tax treaties nonetheless do affect economic behaviour. This can be because of the use of tax haven type intermediaries to shelter deferred taxable income from host countries, so that lowered host country tax rates affect economic behaviour. Transfer pricing and other related devices can also come into play in moving funds in and out of such deferral vehicles and again host country tax rates will matter. And differences, though not that large, do exist in withholding tax rates across OECD countries, and in such a world treaties do change effective tax rates that investors face. Also, if two way investment flows relative to net flows are large, the transfers involved may be relatively small.

A further argument is that tax treaties are negotiated for more than their tax rate provisions. Exchanges of information, such as those relating to holders of bank accounts abroad, can be a powerful incentive for a seemingly lump sum transferring country to negotiate such agreements. Also, linkage between tax treaties and other inter government agreements can be a powerful factor in driving countries into such a negotiation.

Canada, for instance, has for many years been a significant net payer of interest, dividends, and royalties to the United States. As such, lowered withholding tax rates under the Canada-US treaty hurts Canadian interests. But at the same time, Canada gains far more by way of offset from the presence of the US foreign tax credit (some estimates suggest that this provision alone in the US tax code may be worth a considerable portion of Canadian GDP). If negotiating a treaty helps preserve the US foreign tax credit it may become worth negotiating. And if the tax treaty is part of wider cross border policy linkage which underpins NAFTA and other such arrangements, it may again be worthwhile. Treaties can be a way of providing for implicit (and 
non cash) side payments missing in other treaty arrangements, such as in trade. But once again the puzzle as to the national interest involved in negotiating these arrangements on a standalone basis remains.

\section{WHY ARE GOODS AND FACTOR FLOW TREATIES SO DIFFERENT?}

A third puzzle with tax arrangements towards crossborder flows of capital income involves the sharply differing form that international cooperative arrangements take in the seemingly two closely areas of flows of goods and flows of factors. As mentioned in the introduction, some years ago Mundell (1957) in a classic paper pointed out the seeming equivalence between goods and factor flows. This equivalence can be stated in the terms that free flows of goods and common goods prices, under certain conditions, will lead to factor prices being equalized across countries; while free flows of factors and common factor prices across countries will tend to lead to goods prices being equalized across countries. What can be achieved with goods flows can seemingly be equally achieved by factors flows.

Yet while analytically equivalent in this sense, the institutional arrangements for international cooperation with respect to goods and factor flows could hardly be more different. In the goods area both multilateral and regional/bilateral arrangements coexist under multilateral and regional trade treaties. The dominant multilateral component under the World Trade Organization (WTO) has its origins in the General Agreement on Tariffs and Trade (GATT) as negotiated in 1947, under which signatories agree to broad principles which were meant to restrain governments in their use of trade policies. Non-discrimination (Most Favoured Nation States, or MFN) is the most significant of these; but other principles such as national treatment (no discrimination against foreign goods within economies) also enter.

These principles are also accompanied in the 1947 treaty by a best endeavours commitment to try to lower trade barriers through negotiated progressive liberalization. This has lead to the eight negotiating Rounds which have been undertaken under GATT/WTO auspices in the post war years. A dispute settlement procedure completes the structure, with procedures for complaints, 
panels, and eventually GATT/WTO authorized retaliation. But nowhere in this structure are there common tariff rates which apply to both directions of trade flows, or different rates for different types of flows, and unsynchronised bilateral agreements as characterize the tax area.

Thus the tax area, in contrast, appears chaotic in its negotiated outcome. No general set of principles has been agreed, or even contemplated by tax authorities. No system of rights and obligations of governments one towards another in their tax policies applies. Bilateral not multilateral agreements predominate. The negotiation of treaties does not take place simultaneously. Pairs of countries exist between whom there are no tax treaties (especially developing countries). Different tax rates apply to interest, dividends, and royalties; incentives are created to tranship via low treaty rate routes; and other seemingly strange features exist.

Why all these differences? Perhaps the first place to start is to note that theories of how cooperation arises and how it is sustained are relatively sparse in the economics literature. Bargaining solution concepts and their axiomatic underpinnings are set out in a Handbook paper by Thompson (1994), who stresses the widespread use of Nash (1950) bargaining as the fundamental solution concept, as well as the more recent use of Kalai-Smorodinsky (1975) solution concepts, but there is no particular reason why bargaining on trade and investment flow policies should produce a similar institutional outcome.

But beyond this, one also notes the perceived severity of the problem to be solved in the trade case which was to lead to the GATT/WTO. The GATT in 1947 was meant to be the arrangement (along with the unratified International Trade Organization) that was to prevent a repeat of the 1930's and help avoid a post war global recession. Major steps were needed, and major institutional innovation resulted. Later, with the formation of the EU and the EU/US negotiations in the Dillon, Kennedy, and Tokyo Rounds the proof of success from negotiated cooperation became accepted as real. In the international tax area no such pressures either existed earlier, or now exist. The 1930's was not thought to be the outcome of tax competition. An international multilateral tax agreement was not seen as needed to prevent the world reverting to a new recession. 
Also, once established the GATT/WTO was seen as a separate pillar of the global policy system. Global trade negotiations were to only reflect trade interests and trade concerns; the intrusion of other issues (such as environment and labour standards today) has been a recent development. Trade institutions evolved reflecting largely only trade concerns. In the tax area, concessions on tax policy are much more prone to be implicit side payments used to achieve other objectives and hence linked to other parts of the international regime. Signing a tax treaty may be a way to get closer to a trade deal; concessions in a tax treaty were something that could be offered in a multi topic deal.

These and more reasons then provide some loose indications as to why tax and trade arrangements have evolved in such different ways in the post war years despite the formal equivalence set out above. But the puzzle stated above remains.

\section{WHY NO SIDE PAYMENTS IN TREATIES?}

A final puzzle I pose in this area is why tax treaties exist with no side payments. One of the themes emerging from cooperative game theory literature is the need for side payments to support cooperative solutions, including bargained outcomes. This is central, for instance, to Thompson's (1994) survey of bargaining literature referenced above. The implication is that without side payments cooperative arrangements may be unsupportable, and hence one might think that side payments would be a central part of tax treaty arrangements.

The absence of side payments shows itself in a relative absence of bilateral treaties between pairs of countries between whom investment flows are close to being unidirectional. Thus, developing countries are recipients of direct foreign investment with little or no reverse flow. Developing countries typically have higher corporate tax rates than developed countries, and so an OECD model style treaty with a developed country is perceived to provide the majority of benefits to the developed country, and so few are negotiated between these countries. Side payments, however, would seem an obvious mechanism to support such treaties. 
This absence of side payments it should be noted is not confined to international tax treaties, but characterizes other international cooperative arrangements. Trade arrangements in the WTO have no side payments (at least in cash). International environmental agreements also have (effectively) no side payments (see the discussion in Whalley and Zissimos (2001)).

So why no side payments in the tax area? One reason is probably the political unacceptability of payments of cash by one country to another to lower their tax rates. The idea of, say, the US paying Canada (a net recipient of inward bilateral investment) to lower tax rates seems difficult for politicians to convincingly defend.

Another is the linkage of tax treaties to other elements of the international regime mentioned earlier. Specifically, if tax treaties themselves play the role of implicit side payments in order for non-tax treaties to be concluded, the absence of side payments in them becomes perhaps more explicable. This would be the idea that, say, Canada-US trade negotiations are facilitated by a renegotiation of the Canada-US double taxation treaty at around the same time.

At the end of the day, however, game theorists would probably argue that side payments constitute a further instrument for achieving negotiated cooperation; and their absence can seemingly only potentially limit the gains from cooperation. Insofar as developed-developing country tax treaties are effectively precluded by the absence of supporting side payments there seems to be merit in this argument and hence substance to the puzzle.

\section{CONCLUDING REMARKS}

This paper discusses international taxation of investment income, but does so in terms of existing arrangements rather than optimal tax considerations. It characterizes this regime as a series of unilateral reliefs by country from double taxation in the form of foreign tax credit or exemption arrangements, and a bilateral network of treaty reliefs which lower withholding tax rates on interest, dividends, and royalties. The thrust of the paper is to argue that making sense of these 
arrangements in terms either of national interest or in terms of arrangements which maximize gains from cooperation seems difficult. This argument is made by posing four puzzles.

The first is that under either credit or exemption unilateral reliefs private returns to investments across domestic and foreign assets may be equalized in markets, but social returns are not. Where domestic and foreign tax rates are the same, taxes on domestic investments accrue to the home government, but taxes on investments abroad go to the foreign government. The second concerns tax treaties. Where domestic and foreign tax rates are again the same, under credit unilateral reliefs treaties only have lump sum effects. They transfer revenues between governments depending on the net directional flows involved. The third concerns the differences between tax and trade treaties, which sharply diverge in form even though goods and factor flows are often thought to be analytically similar. The fourth concerns the absence of side payments in treaties, which seemingly limit gains from cooperation.

The paper poses these puzzles, and offers some thoughts on how the puzzles can be reconciled suggesting that the present regime is some distance both from national interest and optimal tax literature. The paper also notes the seeming limited literature discussion of these arrangements.

So what does all this suggest for where this regime may be headed under the forces of globalization and tax competition? The first observation is that the structure of this regime has been largely the same for many decades and has large elements of cooperation which have prevailed to stabilize the system and leave it unchanged, even if domestic corporate tax rates have fallen. There are more treaties, but the system shows no signs of major change, nor is there a sense of crisis, system implosion, or other set of strains which would bring major change. The second is that even if hard to explain, the system does embody cooperative elements which most tax competition literature seem to point to as the obvious accommodation to competitive pressures. Some game theorists seem to argue that cooperation is hard to establish, needs some accepted focal point, but once established becomes resilient to all but major system shocks. Perhaps this system fits such a characterization, and tax competition debate will leave it largely intact. 


\section{REFERENCES}

Adams, J.D.R. and J. Whalley (1977), The International Taxation of Multinational Enterprises in Developed Countries, Westport, Conn: Greenwood.

Ault, H.J. and D.F. Bradford (1990), "Taxing International Income: An Analysis of the US System and its Economic Premises" in (ed.) A. Razin and J. Slemrod Taxation in the Global Economy, University of Chicago Press, Chicago, pp. 1-46.

Baccheta, P. and M.P. Espinosa (2000), "Exchange of Information Clauses in International Tax Treaties", International Tax and Public Finance, Vol. 17, pp. 275-293.

Bond, E.W. and L. Samuelson (1989), "Strategic Behaviour and the Rates for International Taxation of Capital”, Economic Journal, 99(398), December, pp. 1099-1111.

Bruce, N. (1992), "Why are There Foreign Tax Credits?" National Bureau of Economic Research Working Paper, July 1992.

Gordon, R. (1986), Taxation of Investment and Saving in a World Economy", American Economic Review, Vol. 76, December, pp. 1086-1102.

Gordon, R.H. and J. D. Wilson (1986), "An Examination of Multi-Jurisdictional Corporate Income Taxation under Formula Apportionment", Econometrica, Vol. 54, November, pp. 1357-73.

Hamada, K. (1966), "Strategic Aspects of the Taxation of Foreign Investment", Quarterly Journal Economics, pp. 361-375.

Hartman, D. (1984), "Tax Policy and Foreign Direct Investment in the United States", National Tax Journal, Vol. 37, pp. 475-87.

Hartman, D.G. (1985), “Tax Policy and Foreign Direct Investment”, Journal of Public Economics, Vol. 26, pp. 107-121.

Hines, J.R. (1994), "Credit and Deferral as International Investment Incentives", Journal of Public Economics, Vol. 55, No. 2, October, pp. 323-347.

Hines, J.R. (19 ), “The Case against Deferral: A Deferential Reconsideration”, National Tax Journal, Vol. 52, No. 3, pp.385-404.

Horst, T. (1980), "A Note on the Optimal Taxation of International Investment Income", Quarterly Journal of Economics, Vol. 44, June, pp. 793-798.

Janeba, E. (1995), "Corporate Income Tax Competition, Double Taxation Reliefs, and Foreign Direct Investment", Journal of Public Economics, Vol. 56, pp. 311-325. 
Johnson H.G. (1954) "Optimal Tariffs and Retaliation" Review of Economic Studies, vol. 21, pp. 142-53.

Kalai E. and M. Smorodinsky (1975) "Other Solutions to Nash's Bargaining Problem", Econometrica, vol. 43, pp. 513-518.

Mintz, J.M. and H. Tulkens (1991), "The OECD Convention: A "Model" for Corporate Tax Harmonization" in (ed.) Prud'homme R. Public Finance with Several Levels of Government, Foundation Journal Public Finance, the Hague, 1991.

Markusen, J. (1983), "Factor Movements and Commodity Trade as Complements", Journal of International Economics, Vol. 14 No. 3-4, May, pp. 341-356.

Mundell, R.A. (1957), "International Trade and Factor Mobility”, American Economic Review, Vol. 47(3), June, pp. 321-35.

Musgrave, P. B. (1969), United States Taxation of Foreign Source Income: Issues and Arguments, Harvard University Press, Cambridge, Mass.

Nash J.F. (1950) "The Bargaining Problem" Econometrica, vol. 28, pp. 155-62.

Razin, A. and J. Slemrod (ed.) (1990), Taxation in the Global Economy, University of Chicago Press, Chicago.

Richman, P.B. (1963), Taxation of Foreign Investment Income: An Economic Analysis, Baltimore, Johns Hopkins Press.

Slemrod, J. (1988), "International Capital Mobility and The Theory of Capital Income Taxation" in (ed.) H.J. Aaron, H. Galper, and J.A. Peckman, Uneasy Compromise: Problems of Hybrid Income-Consumption Tax, Washington D.C., Brookings.

Thompson W. (1994) "Cooperative Models of Bargaining" in ed. R.J. Aumann and S. Hart Handbook of Game Theory, vol. 2, 1994, Elsevier Science B.V.

Wilson, J.D. (1999), “Theories of Tax Competition", National Tax Journal, Vol 52, No. 2, June, pp. 269-304. 